\title{
Classification of bifid mandibular canals in the Syrian population using panoramic radiographs
}

S. Kasabah ${ }^{7}$ and Y. Modellel

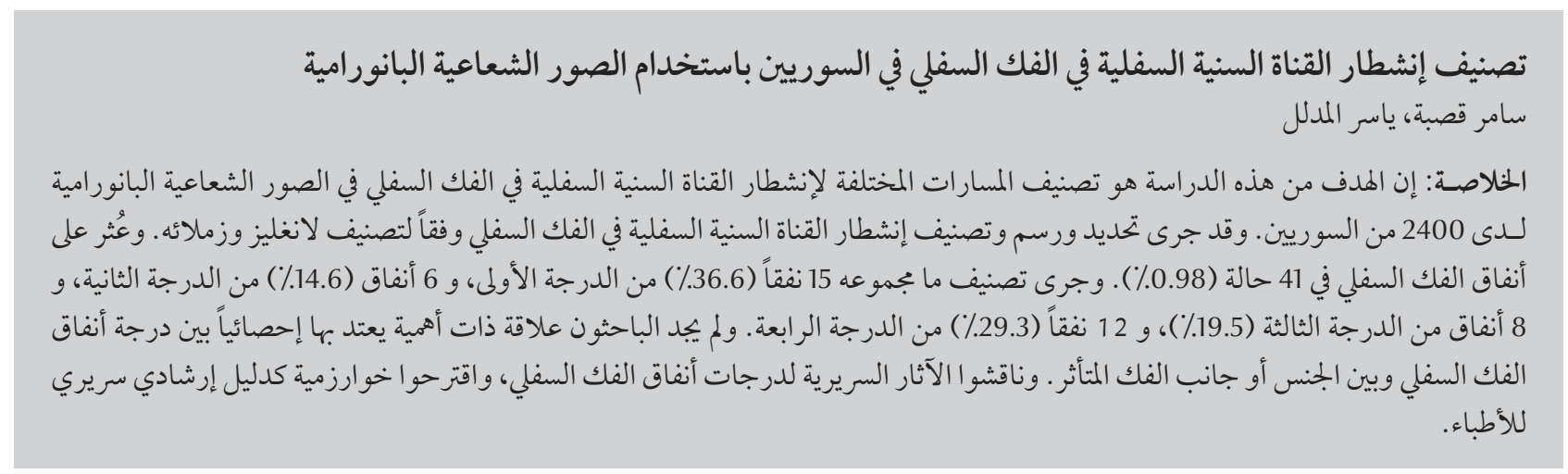

ABSTRACT The objective of this study was to classify the different routes of the bifid mandibular canals (BMCs) on 2400 panoramic radiographs in a Syrian population. BMCs were identified, drawn and classified according to the classification of Langlais et al. BMCs were found in 41 cases (0.98\%). A total of 15 canals (36.6\%) were classified as Class I, 6 canals (14.6\%) as Class II, 8 canals as Class III (19.5\%) and 12 canals (29.3\%) as Class IV. There was no statistically significant association between BMC class and sex or affected jaw side prevalence. The clinical implications of BMC classes are discussed and an algorithm is suggested as a clinical guide for clinicians.

Classification des canaux mandibulaires bifides dans la population syrienne à l'aide de radiographies panoramiques

RESUME L'objectif de la présente étude était de classer les différents trajets des canaux mandibulaires bifides sur 2400 radiographies panoramiques dans une population de Syriens. Des canaux mandibulaires bifides ont été identifiés, dessinés puisclassésselonlaclassification de Langlaisetal.Uncanalmandibulairebifideaétéobservédans 41 cas $(0,98 \%)$. Au total, 15 canaux (36,6\%) ont été attribués à la Classe I, 6 canaux (14,6\%) à la Classe II, 8 canaux à la Classe III (19,5\%) et 12 canaux (29,3\%) à la Classe IV. Aucune association statistiquement significative n'a été observée entre la classe du canal mandibulaire bifide et le sexe ou la prévalence du côté affecté de la mâchoire. Les implications cliniques des classes de canaux mandibulaires bifides font l'objet de discussions et un algorithme est suggéré pour guider les cliniciens dans leur évaluation clinique. 


\section{Introduction}

The mandibular canal passes through the mandible from the mandibular foramen to the mental foramen, involving the inferior alveolar nerve, artery and vein. Common variations are seen with respect to the anatomy and location of the mandibular canal. One such anatomical variation is known as a bifid mandibular canal (BMC). BMCs can be seen on panoramic radiograph [1-3]. Using panoramic radiographs, different types of BMCs have been classified based on anatomical location, configuration and patterns of duplication [3-6].

Langlais et al. [3] described four patterns of duplication:

- Type I represents unilateral or bilateral bifid canals that extend to the mandibular third molar area or the immediately surrounding area;

- Type II includes unilateral or bilateral bifid canals that rejoin within the ramus of the mandible or extend into the body;

- Type III is a combination of Types I and II;

- Type IV has two canals, each of which originates from a separate mandibular foramen, joining to form one larger canal.

Langlais et al. also stated that normal canals or bifid canals may have additional smaller accessory canals [3].

It is important for dentists to be able to identify BMCs so that they may choose a suitable technique for administering anaesthesia and prevent potential complications that may have serious consequences during surgery in the mandibular region $[7,8]$. The aim of the study was to classify the BMCs found in a sample of the Syrian population and to give clinical implications for this classification to be used by clinicians to identify these BMCs on panoramic radiographs, and to prevent and manage complications that may arise as a result of their presence.

\section{Methods}

The courses of the mandibular canal in 4200 panoramic radiographs of Syrian subjects (1899 women and 2301 men), ranging in age from 18 to 55 years (mean age 37 years) were evaluated carefully. Radiographs were visualized with the help of a radiographic film viewer (negatoscope) and a magnifying glass. Subjects presenting radiographic images compatible with unilateral or bilateral BMCs were recorded and, when identified, these images were drawn manually on translucent paper. The drawings included the condyles, ramus, lower teeth, mandibular and mental foramens, mandibular canal and mandibular lower border. All drawings were analysed by three observers and the classification proposed by Langlias et al. [3] was used to classify them into four classes (Figure 1). The prevalence of each BMC class was also recorded according to the patient's sex and whether the BMC was in the right or left side of the mandible. Effects of sex, type and side of the jaw on BMC class occurrence were statistically evaluated using the chi-square test $(P$ $=0.05$ ).

\section{Results}

Of the panoramic radiographs, 41 cases (0.98\%) demonstrated a BMC (Figure 2). According to Langlais's classification, Class I BMCs were unilateral in 14 radiographs (36.6\%), affecting males and females equally. A larger number of BMCs was verified on the left side of the mandible (eight radiographs) against six occurrences on the right side, while only one case was presented bilaterally, representing $0.02 \%$ of the total number studied and $3.3 \%$ of cases presenting with BMCs (Table 1).

Class II BMCs were observed in six radiographs (14.6\%), being divided equally between males and females. They occurred three times on the right side, twice on the left side and once bilaterally (Table 1).

Class III BMCs were observed unilaterally in eight cases (19.5\%), five on the right side and three on the left side. Five cases were males while three were females (Table 1).

Class IV BMCs were identified bilaterally on one image and unilaterally on 11 images (28.9\%); five were in males and six in females. Six were on the right side and five were on the left side (Table 1).

No statistically significant effects of sex and affected side of the jaw on BMC class prevalence were observed (Table 1).

Based on the classifications of BMC, we suggest an algorithm that could be used as a clinical guide (Table 2).

\section{Discussion}

Panoramic radiographs are an important auxiliary resource in diagnosis and dental treatment [9]. Therefore, it is of considerable interest for dentists to identify the presence of BMCs on panoramic radiographs in order to provide better patient care. BMCs have been observed using different imaging methods: panoramic radiographs alone, panoramic images in association with other two-dimensional radiological investigations, computerized tomography (CT), cone beam CT and CT-based planning software (three-dimensional) [10-16].

Our results disagree with the results obtained by other authors (Figure 3). Class I was the most prevalent in this study (36.6\%) and similar results were reported in other studies $[9,10]$. Class II was the least prevalent in this study (14.6\%), which is in disagreement with observations in the other studies; indeed, Class II occurrence was the highest in half of the studies compared (Figure 3). Class III was thus not the least prevalent class in both the present 


\section{Type 1}

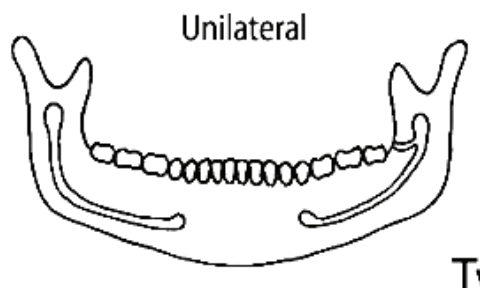

\section{Type 2}

Unilateral, limited to ramus

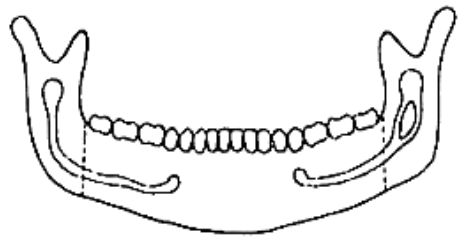

Bilateral, limited to ramus

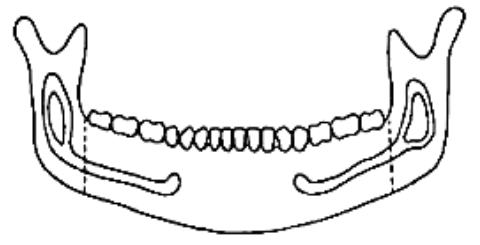

Type 3

Combination of Types 1 and 2

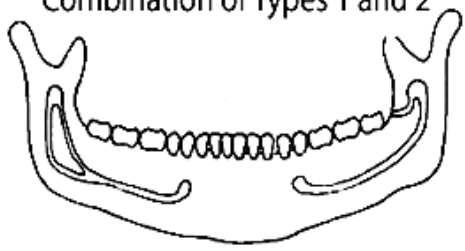

Unilateral, extending into body
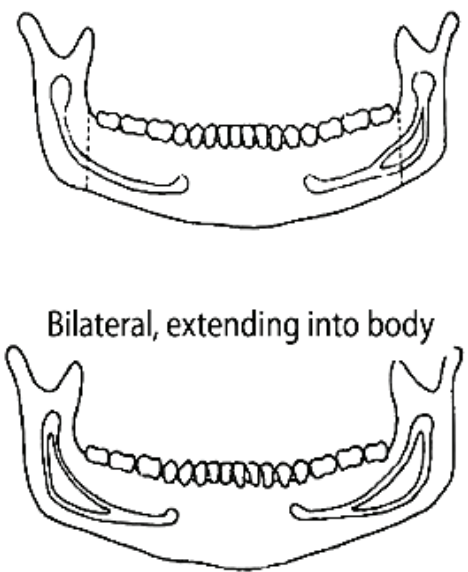

Type 4

Originating from two mandibular foramens
Bilateral, extending into body

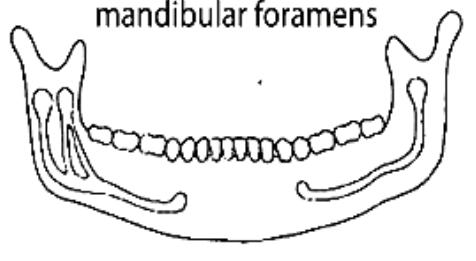

Figure 1 Proposed classification [3]

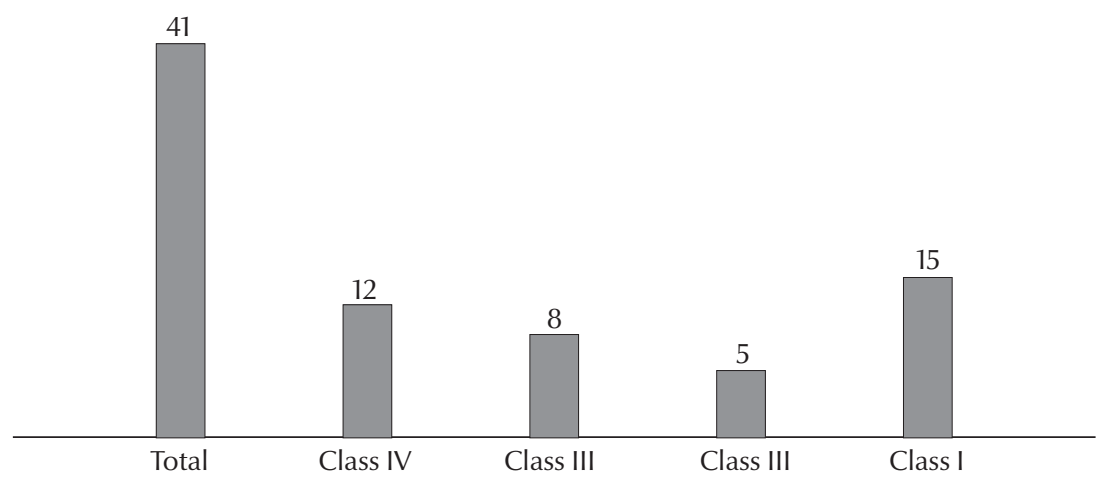

Figure 2 Number of cases of bifid mandibular canal in each class group study and that of Devito and Tamburús [17], unlike in other studies [18-21].

The prevalence of Class IV showed the highest variation between the published studies (Figure 3). In our study, Class IV was observed in $29.3 \%$ of cases, in agreement with the percentage reported by Rossi et al. [18] and Salvador et al. [19] (34.9\% and 34.6\%, respectively). However, this is almost twice the number of cases observed by Akgunlu and Kansu [20] (17.8\%) and much greater than those reported by Valarelli (11.8\%) [21], Devito and Tamburús (2\%) [17] and Langlais et al. (3.5\%) [3].

Only one study has looked at patient sex in relation to BMCs classification [19]. In the present study, the most prevalent class was Class I, equally prevalent in both males and females, and the lowest prevalent class was Class II in both sexes. However, this was not the case in Salvador et al.'s study [19] where the most prevalent class was Type II in women and Type IV in males and the lowest prevalent class was Type III in both sexes. However, in both studies, the difference was not statistically significant.

According to our knowledge, no previous study has looked at the relationship between BMC class and the affected side; however, the results of this study showed no statistically significant relationship (Table 1).

Recognition of BMC is important because of its clinical implications [22]. Inadequate anaesthesia may occur with any BMC type, but especially when there are two mandibular foramens (Class IV), which was the second most common class in this study [16,23-27]. It is important for the dentist to be able to perform mandibular anaesthesia at a higher level before the division of the mandibular nerve, the so-called GowGates technique $[3,8]$. This might be advised to undergraduates in Syrian dental faculties.

Moreover, the presence and classification of BMCs are important in 


\begin{tabular}{|c|c|c|c|c|c|c|c|c|}
\hline BMC type & Sex & BMC side & $\begin{array}{c}\text { Class I } \\
\text { No. (\%) }\end{array}$ & $\begin{array}{l}\text { Class II } \\
\text { No. (\%) }\end{array}$ & $\begin{array}{l}\text { Class III } \\
\text { No. (\%) }\end{array}$ & $\begin{array}{l}\text { Class IV } \\
\text { No. (\%) }\end{array}$ & $\begin{array}{c}\text { Total } \\
\text { No. (\%) }\end{array}$ & $P$-value \\
\hline \multirow{9}{*}{ Unilateral } & \multirow{2}{*}{ Male } & Right & $5(38.5)$ & $2(15.4)$ & $3(23.1)$ & $3(23.1)$ & $13(100)$ & \multirow{2}{*}{0.971} \\
\hline & & Left & $2(28.6)$ & $1(14.3)$ & $2(28.6)$ & $2(28.6)$ & $7(100)$ & \\
\hline & \multirow{2}{*}{ Female } & Right & $1(14.3)$ & $1(14.3)$ & $2(28.6)$ & $3(42.9)$ & $7(100)$ & \multirow{2}{*}{0.366} \\
\hline & & Left & $6(54.5)$ & $1(9.1)$ & $1(9.1)$ & $3(27.3)$ & $11(100)$ & \\
\hline & \multirow{2}{*}{ Both } & Right & $6(30)$ & $3(15)$ & $5(25)$ & $6(30)$ & $20(100)$ & \multirow{2}{*}{0.808} \\
\hline & & Left & $8(44.4)$ & $2(11.1)$ & $3(16.7)$ & $5(27.8)$ & $18(100)$ & \\
\hline & Male & Both sides & $7(35)$ & $3(15)$ & $5(25)$ & $5(25)$ & $20(100)$ & \multirow{2}{*}{0.876} \\
\hline & Female & Both sides & $7(38.9)$ & $2(11.1)$ & $3(16.7)$ & $6(33.3)$ & $18(100)$ & \\
\hline & \multicolumn{2}{|c|}{ All unilateral BMC subjects } & $14(36.8)$ & $5(13.2)$ & $8(21.1)$ & $11(28.9)$ & $38(100)$ & \multirow{4}{*}{0.223} \\
\hline \multirow{3}{*}{ Bilateral } & \multicolumn{2}{|l|}{ Male } & $1(50)$ & $0(0)$ & $0(0)$ & $1(50)$ & $2(100)$ & \\
\hline & \multicolumn{2}{|l|}{ Female } & $0(0)$ & $1(100)$ & $0(0)$ & $0(0)$ & $1(100)$ & \\
\hline & \multicolumn{2}{|c|}{ All bilateral BMC subjects } & $1(33.3)$ & $1(33.3)$ & $0(0)$ & $1(33.3)$ & $3(100)$ & \\
\hline \multirow{3}{*}{ Both } & Male & Both sides & $8(36.4)$ & $3(13.6)$ & $5(22.7)$ & $6(27.3)$ & $22(100)$ & \multirow{3}{*}{0.951} \\
\hline & Female & Both sides & $7(36.8)$ & $3(15.8)$ & $3(15.8)$ & $6(31.6)$ & $19(100)$ & \\
\hline & \multicolumn{2}{|c|}{ All BMC subjects } & $15(36.6)$ & $6(14.6)$ & $8(19.5)$ & $12(29.3)$ & $41(100)$ & \\
\hline \multicolumn{3}{|c|}{ \% Total sample ( $n=4200$ subjects) } & 0.36 & 0.14 & 0.19 & 0.29 & 0.98 & \\
\hline
\end{tabular}

$B M C=$ bifid mandibular canal.

surgical procedures involving the mandible. Complications such as traumatic neuroma, paraesthesia and bleeding can occur during oral and maxillofacial surgery because of possible damage to an unidentified BMC. In particular, this should be considered during extraction of an impacted third molar, dental implant treatment, traumatology and reconstructive surgery, and orthognathic surgery (bilateral sagittal split ramus osteotomy technique) $[6,11,28]$. In pam tients wearing prostheses, this condition can cause pain and discomfort due to bone resorption [22].Using implants in these patients can also cause damage to the BMC [11]. The retromolar region was used as a donor site for harvesting bone blocks [29-31]. To safely harvest bone blocks from the retromolar region, preoperative imaging using cone beam CT may be needed. Also, the identification of dental canal presence may be important in extraction.

\begin{tabular}{|c|c|c|c|}
\hline Identification features & $\begin{array}{l}\text { Implications for general } \\
\text { dentist }\end{array}$ & $\begin{array}{l}\text { Implications for oral surgery } \\
\text { and dental implantology }\end{array}$ & $\begin{array}{l}\text { Implications for } \\
\text { maxillofacial surgery }\end{array}$ \\
\hline \multicolumn{4}{|c|}{ Class I BMCs } \\
\hline $\begin{array}{l}\text { Triangular island of bone with its } \\
\text { vertex at the root of separation } \\
\text { of BMCs }\end{array}$ & $\begin{array}{l}\text { Usually none if the treatment } \\
\text { does not involve the } 3 \mathrm{rd} \\
\text { molar }\end{array}$ & $\begin{array}{l}\text { Extraction of 3rd molar } \\
\text { Retromolar graft harvesting } \\
\text { Local anaesthesia: usually } \\
\text { none if the inferior alveolar } \\
\text { block is given before the } \\
\text { nerve enters the canal }\end{array}$ & Orthograntic surgery (BSSO) \\
\hline \multicolumn{4}{|c|}{ Class II BMCs } \\
\hline $\begin{array}{l}\text { Triangular island of bone with its } \\
\text { vertex at the root of separation } \\
\text { of BMCs }\end{array}$ & $\begin{array}{l}\text { Root canal treatment of the } \\
\text { 2nd and 3rd }\end{array}$ & $\begin{array}{l}\text { When extending into body: } \\
\text { Caution with implant surgery } \\
\text { in } 2^{\text {nd }} \text { and } 3^{\text {rd }} \text { molar are (rare) } \\
\text { Mini-implant placement } \\
\text { Retromolar/body bone graft }\end{array}$ & $\begin{array}{l}\text { When extending into body: } \\
\text { Orthograntic surgery (BSSO, } \\
\text { mini-plate placement) } \\
\text { Traumatology }\end{array}$ \\
\hline \multicolumn{4}{|c|}{ Class IV BMCs } \\
\hline $\begin{array}{l}\text { Two distinct radiolucent canals } \\
\text { join posteriorly, one anterior } \\
\text { another, separated usually by an } \\
\text { island of medullary bone }\end{array}$ & $\begin{array}{l}\text { If an inferior alveolar block } \\
\text { is ineffective, Gow-Gate } \\
\text { injection is recommended }\end{array}$ & $\begin{array}{l}\text { When extending into body: } \\
\text { Caution with implant surgery } \\
\text { in 3rd molar (rare) } \\
\text { Retromolar/body bone graft }\end{array}$ & $\begin{array}{l}\text { When extending into body: } \\
\text { Orthograntic surgery (BSSO) } \\
\text { Traumatology }\end{array}$ \\
\hline
\end{tabular}

$B M C=$ bifid mandibular canal; $B S S O=$ bilateral sagittal split ramus osteotomy technique . 


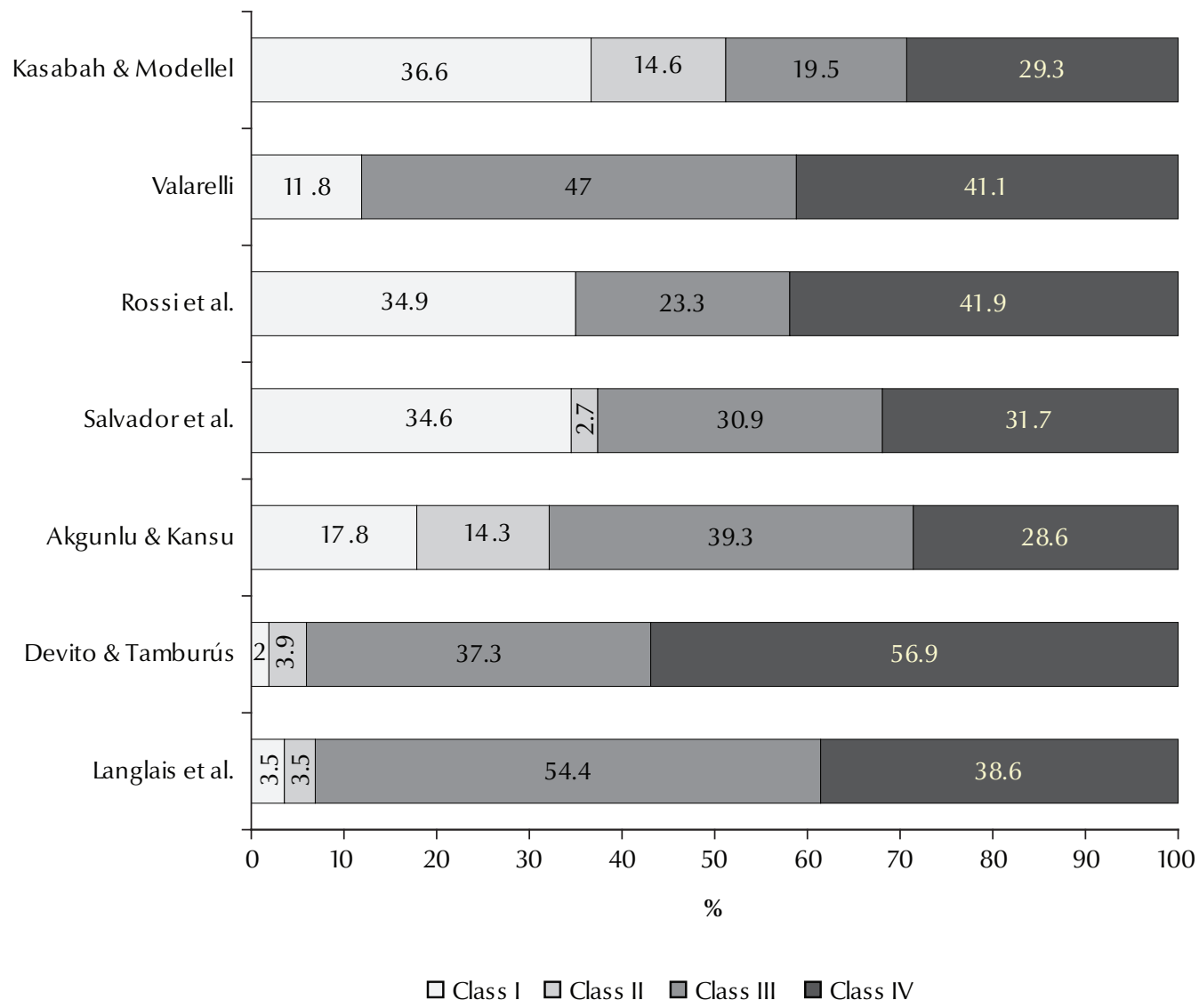

Figure 3 Comparison of our results with the results obtained by other authors, expressed as a percentage of the total bifid mandibular canals found

The incidence of accessory mandibular foramina (AMF) has been found to be greater on the medial surface than on the lateral surface $[32,33]$. These accessory foramina are known to transmit the branches of facial, mylohyoid, buccal and transverse cervical cutaneous nerves [34]. During routine dental extractions, nerve block by local anaesthesia may fail if the branches of the inferior alveolar nerves pass through these accessory foramina and thus escape anaesthesia. The canal leading from AMF terminates close to the root of the third molar [35]. This implies that any nerve passing through AMF may possibly be supplying the third molar, as seen in this case. This kind of alternative route of passage of any nerve supplying the third molar may be responsible for the failure of dental nerve block. Awareness of the presence of AMF may be important in achieving successful inferior alveolar nerve anaesthesia and so this is best performed at a higher level using the Gow-Gates technique [8].

As AMF is known to provide an easy route for the spread of tumour cells following radiotherapy [36-38], the presence of AMF may be important for oncologists in planning radiation therapy. AMF might also provide an easy route for the spread of infection. Thus, knowledge of the anatomical details of AMF may be of significant clinical interest to surgeons and oncologists in clinical practice.

Surgeons performing conservative rim resection procedures should keep in mind tumour involvement in the region of AMF and plan the operative procedure accordingly. The presence of AMF may be important in orthognathic or reconstructive surgery of the mandible and during dental implants $[11,38]$.

The algorithm we propose in Table 2 will help clinicians identify, avoid and manage complications that may arise as a result of the presence of BMCs.

Competing interests: None declared.

\section{References}

1. Wyatt WM. Accessory mandibular canal: literature review and presentation of an additional variant. Quintessence International, 1996, 27:111-113.
2. Sanchis JM, Penarrocha M, Soler F. Bifid mandibular canal. Journal of Oral and Maxillofacial Surgery, 2003, 61(4):422424. 
3. Langlais R, Broadus R, Glass BJ. Bifid mandibular canals in panoramic radiographs. Journal of the American Dental Association, 1985, 110:923-926.

4. Nortje C, Farman A, Grotepass F. Variations in the normal anatomy of the inferior dental (mandibular) canal: a retrospective study of panoramic radiographs from 3612 routine dental patients. British Journal of Oral Surgery, 1977, 15:55-63.

5. Nortje C, Farman A, de Joubert J. The radiographic appearance of the inferior dental canal: an additional variation. British Journal of Oral Surgery, 1977, 15:171-172.

6. Singh $\mathrm{S}$ et al. Morphologic variations in the mandibular canal: a retrospective study of panoramic radiographs. Journal of Oral Health Research, 2010, 1:106-112.

7. Langlais RP, Broadus R, Glass BJ. Bifid mandibular canals in panoramic radiographs. Journal of the American Dental Association, 1985, 110:923-926.

8. Meechan JG. How to overcome failed local anaesthesia. British Dental Journal, 1999, 186:15-20.

9. Stuart C, ed. Oral radiology, principles and interpretation, 5th ed. St Louis, MO, Elsevier, 2006:184.

10. Klinge B, Petersson A, Maly P. Location of the mandibular canal: comparison of macroscopic findings, conventional radiography, and computed tomography. International Journal of Oral \& Maxillofacial Implants, 1989, 4:327-332.

11. Quattrone G, Furlini E, Bianciotto M. Bilateral bifid mandibular canal. Presentation of a case. Minerva Stomatologica, 1989, 38:1183-1185.

12. Naitoh $M$, Hiraiwa $Y$, Aimiya H. Bifid mandibular canal in Japanese. Implant Dentistry, 2007, 16:24-32.

13. Naitoh $\mathrm{M}$ et al. Observation of bifid mandibular canal using cone-beam computerized tomography. International Journal of Oral \& Maxillofacial Implants, 2009, 24:155-159.

14. De Oliveira-Santos $C$ et al. Assessment of variations of the mandibular canal through cone beam computed tomography. Clinical Oral Investigations, 2012, 16:387-393.

15. Orhan $\mathrm{K}$ et al. Evaluation of bifid mandibular canals with conebeam computed tomography in a Turkish adult population: a retrospective study. Surgical and Radiologic Anatomy, 2011, 33:501-507.

16. Sanchis J, Penarrocha M, Soler F. Bifid mandibular canal. Journal of Oral and Maxillofacial Surgery, 2003, 61:422-424.

17. Devito KL, Tamburús JR. Anatomia do canal da mandíbula classificação radiográfica das variações [Anatomy of the mandibular canal: radiografic classification of variations]. Revista da Associação Paulista de Cirurgiões Dentistas, 2001, 55:261-266.

18. Rossi P, Brucker M, Rockenbach M. Bifid mandibular canals: panoramic radiographic analysis. Revista de Ciências Médicas (Campinas), 2009, 18:99-104.

19. Salvador J et al. Radiographic anatomy of the mandibular canal and its variations in panoramic radiographs. Innovations Implant Journal: Biomaterials and Esthetics, 2010, 5:19-24.

20. Akgunlu F, Kansu O. Panoramik Radiyograflarda Bifid Mandibular Kanallarin Siniflandirilmasi [Classification of bifid mandibular canal using panoramic radiographs]. Cumhuriyet Üniversitesi. Diş Hekimliği Fakültesi Dergisi, 2000, 3:63-65.
21. Valarelli T et al. Interpretação radiográfica do canal mandibular em radiografias panorâmicas [Radiographic interpretation of the mandibular canal in panoramic radiographs] (http://www. actiradentes.com.br/revista/2007/textos/2RevistaATO-Interpretacao_radiografica_canal_mandibular-2007.pdf, accessed 30 May 2013).

22. Claeys V, Wackens $\mathrm{G}$. Bifid mandibular canal: literature review and case report. Dentomaxillofacial Radiology, 2005, 34:55-58.

23. Grover $\mathrm{P}$, Lorton L. Bifid mandibular nerve as a possible cause of inadequate anesthesia in the mandible. Journal of Oral and Maxillofacial Surgery, 1983, 41:177-179.

24. Desantis JL, Liebow C. Four common mandibular nerve anomalies that lead to local anesthesia failures. Journal of the American Dental Association, 1996, 127:1081-1086.

25. Wong MK, Jacobsen PL. Reasons for local anesthesia failures. Journal of the American Dental Association, 1992, 123:69-73.

26. Madan GA, Madan SG, Madan AD. Failure of inferior alveolar nerve block: exploring the alternatives. Journal of the American Dental Association, 2002, 133:843-846.

27. Lew K, Townsen G. Failure to obtain adequate anaesthesia associated with a bifid mandibular canal: a case report. Australian Dental Journal, 2006, 51:86-90.

28. Dario L. Implant placement above a bifurcated mandibular canal: a case report. Implant Dentistry, 2002, 11:258-261.

29. Khoury F. Augmentation of the sinus floor with mandibular bone block and simultaneous implantation: a 6-year clinical investigation. International Journal of Oral \& Maxillofacial Implants, 1999, 14:557-564.

30. Nkenke E et al. Morbidity of harvesting of retromolar bone grafts: a prospective study. Clinical Oral Implants Research, 2002 13:514-521.

31. Yildirim $M$ et al. Maxillary sinus augmentation with the xenograft Bio-Oss and autogenous intraoral bone for qualitative improvement of the implant site: a histologic and histomorphometric clinical study in humans. International Journal of Oral \& Maxillofacial Implants, 2001 16:23-33.

32. Fanibunda K, Matthews J. Relationship between accessory foramina and tumour spread in the lateral mandibular surface. Journal of Anatomy, 1999, 195:185-190.

33. Haveman CW, Tebo HG. Posterior accessory foramina of the human mandible. Journal of Prosthetic Dentistry, 1976, 35:462-468.

34. Gray $\mathrm{H}$ et al. Gray's anatomy. London, Churchill Livingstone, 1995.

35. Das S, Suri RK. An anatomico-radiological study of an accessory mandibular foramen on the medial mandibular surface. Folia Morphologica, 2004, 63:511-513.

36. Browne J, Browne R. Factors influencing the pattern of invasion of the mandible by oral squamous cell carcinoma. International Journal of Oral \& Maxillofacial Implants, 1995, 24:417-426.

37. Lukinmaa $\mathrm{P}$ et al. The histologic pattern of bone invasion by squamous cell carcinoma of the mandibular region. British Journal of Oral and Maxillofacial Surgery, 1992, 30:2-7.

38. Slootwerg $\mathrm{P}$, Muller H. Mandibular invasion by squamous cell carcinoma. Journal of Cranio-Maxillofacial Surgery, 1989, 17:69-74. 